\title{
The Gas Diffusion Layer in High Temperature Polymer Electrolyte Membrane Fuel Cells
}

\author{
Justo Lobato, Pablo Cañizares, Manuel A. Rodrigo and José J. Linares \\ Chemical Engineering Department, University of Castilla-La Mancha
}

Spain

\section{Introduction}

\subsection{Polymer electrolyte membrane fuel cells. Operation at high temperature $\left(120-200^{\circ} \mathrm{C}\right)$}

\subsubsection{General overview}

Polymer Electrolyte Membrane Fuel Cells (PEMFC) can be considered as one of the most attractive type of fuel cells. They are able to produce efficiently high power densities. In addition, the use of a polymer electrolyte implies several advantages (Fuel Cell Handbook, 2004), such as low problems of sealing, assembling and handling. No corrosive acids, compared to Phosphoric Acid Fuel Cells (PAFC) are used, and the low temperature of the cell allows faster responses to changes in load demands. The characteristics of these cells make them especially suitable for automotive applications, even though they are also used for stationary generation, and currently, there is a great research effort for its application on portable devices (laptops, mobile phones, cameras, etc.).

PEMFC are composed of the following basic elements:

- Ionic exchange membrane (PEM).

- Gas diffusion layer (GDL).

- Catalytic layer (CL).

- Monopolar/bipolar (in case of a stack) plates.

The combination of the GDL+CL+PEM forms the membrane-electrode-assembly (MEA), which is the real heart of a PEMFC. This MEA can be formed by applying pressure and temperature to the (GDL+CL) in the anode side/PEM/(GDL+CL) in the cathode side (hot pressing procedure), or by directly depositing the CL onto the PEM, and subsequent hot pressing with the GDL.

Ionic exchange membrane fulfils the role of allowing the transient of ionic charges from the anode to the cathode, closing the electrical circuit. It also possesses a low permeability to the gases, in order to avoid the depolarization of the electrode (Savadogo, 2004). A high mechanical and chemical stability is also required for these materials, due to the harsh operational conditions (oxidant and reducing gases in an acid medium). The most extended PEM material is Nafion ${ }^{\circledR}$, a perflurosulphonated material, whose structure consists of a perfluorocarbon skeleton (Teflon-like), onto which, branch chains with pendant sulphonic acid groups are located, allowing the transient of ionic charges (see Figure 1). 


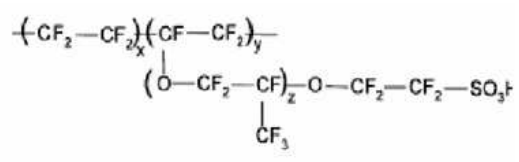

(a)

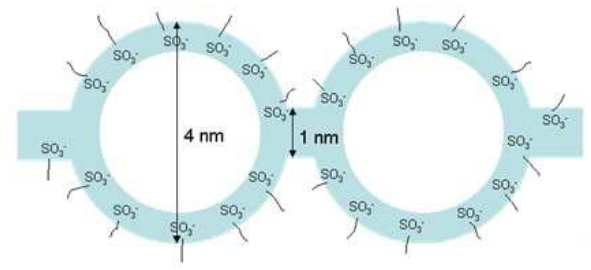

(b)

Fig. 1. (a) Nafion structure, (b) organization within the Nafion membranes of the hydrophilic domains (blue) allowing the transient of protons

The gas diffusion layer (GDL) is placed between the catalytic layer and the bipolar plates (Cindrella et al., 2009). It will be later explained in more detail, but its basic function is to manage the access of the reactants, and the exit of the products (Benziger et al., 2005; Mathias et al., 2003; Williams et al., 2004). This layer is made of a carbonaceous support, onto which it can be deposited another layer, the microporous layer (MPL), formed by carbon black and a certain amount of a polymer binder. In traditional low temperature, this GDL also playes the role of an effective removal of the liquid water is produced in the cathode, in order to avoid the flooding of the electrode (Benziger et al., 2005; Mathias et al., 2003; Prasanna et al., 2004a).

The catalytic layer is the part of the cell where the electrochemical reactions take place. It is placed between the electrolyte and the gas diffusion layer (Mathias et al., 2003). This layer is generally formed by the own catalyst deposited on a porous carbon support. The most widely used catalyst for the reactions that take place in the cell (hydrogen oxidation and oxygen reduction) is platinum. A second element of this layer is the own carbon support, which acts as electronic conductor, and allows the dispersion of the platinum catalyst on its surface. The role of binder between the catalyst particle is performed by the own polymeric electrolyte. This also presents an additional advantage, since the catalyst active sites are in intimate contact with an ionic carrier, increasing its activity (Carrete et al., 2001). This apparent network is widespread all over the catalyst layer structure, forming the so-called three phase boundary.

Monopolar/Bipolar plates are the last element of a fuel cell. They act as support of the previous described elements, allow the access and exit of the reactants and products, respectively, and must allow an uniform current distribution/collection. At laboratory scale, the most widely used material is graphite. However, its high cost and fragility make it relatively unviable for practical applications. Instead stainless steel or titanium plates are proposed, even though platinum, gold or silver plating are recommended in order to alleviate the corrosion problems of those raw materials.

\subsubsection{Increasing the operating temperature}

Operating at temperatures above $100^{\circ} \mathrm{C}$ possesses some advantages (Li et al., 2003a; Li et al., 2004; Savadogo, 2004; Wainright et al., 2003):

- $\quad$ Faster kinetic of the electrochemical reactions.

- Easier water management and cooling system

- Possibility of co-generation.

- Higher tolerance to fuel impurities (e.g., CO) (Li et al., 2003b). 
This implies the use of a thermal resistant material, which, at the same time, has to be a proton conductor. A large number of option have been researched and developed in order to increase the operational temperature (Bose et al., 2011). However, among the different options, phosphoric acid impregnated polybenzimidazole (PBI) has emerged as the most interesting and well-established one.

Firstly discover for fuel cell applications by Prof. Savinell's group in Case Western Research University (Wainright et al., 2003), PBI is an aromatic heterocyclic polymer with two benzimidazolic ring linked by a phenyl group. It possesses a high thermal and chemical resistance, with a glass transition temperature of approx. $450^{\circ} \mathrm{C}$ (Wainright et al., 2003), as corresponds to a thermoplastic amorphous polymer with a high degree of aromaticy. Benzimidazole groups of PBI provide certain basicity, allowing the impregnation with phosphoric acid. Some advantages of the use of this material are next listed:

- Good conductivity up to $200^{\circ} \mathrm{C}$ (Li et al., 2004, Lobato et al., 2006).

- Low methanol permeability (Wang et al., 1996, Lobato et al., 2008a).

- Excellent thermal stability, up to $500^{\circ} \mathrm{C}$ in air (Samms et al., 1996).

- Almost zero electro-osmotic drag coefficient (Weng et al., 1996), making unnecessary the pre-humidification of the reactant streams.

- Enhancement of the kinetic of the oxygen reduction reaction compared to PAFC (Qingfeng et al., 2000).

\section{Mass transport in polymer electrolyte membranes fuel cells}

As previously described, a fuel cell is an electrochemical reactor, in which reactants are consumed, and consequently, new products are generated. This evidently leads to the appearance of concentration gradients, giving rise to mass transport phenomena. In addition, the complex design of the electrodes, with several layers sandwiched together, and the convoluted architecture of each one make it even more difficult the transport of the different species from/to the electrode, leading to the appearance of mass transport limitations if the system design is not the appropriate one.

Mass transport processes already start in the flow fields of the monopolar/bipolar plates. In them, the reactant gases access to the fuel cell system, whereas the products have to leave it. Due to the dimensions of the flow fields, in the scale of millimeters, mass transport is dominated by convection and the corresponding laws of fluid dynamics. In the case of the electrode (GDL+CL), the tiny pore sizes make diffusion to govern the mass transport. The tortuous geometry of the GDL+CL isolates the gas molecules from the convective forces present in the flow channels. Gas transport inside the electrode is a complex processes. The gas must diffuse within the gas diffusion layer, to achieve the catalytic layer, and then, inside this, the gas must access to the active catalyst sites. These catalyst sites are usually covered by a certain amount of electrolyte (Lai et al., 2008; Lobato et al., 2010a), and hence, the reactant gases and the products must also diffuse through it, complicating, even more, the mass transfer processes. Figure 2 shows a typical concentration/partial pressure profile of a PEMFC.

Mass transfer processes have implications in practically all the elements of the fuel cell. In the case of the flow field channels, they should provide an homogeneous distribution across the electrode external surface, minimize the pressure drop, and efficiently remove the product reactions. In the case of the GDL, the requirements are almost the same, even though the inexistence of convection forces makes more difficult the access of the reactants, 
and the removal of the products. Thereby, this elements is notoriously more critical in this sense. The catalytic layer also requires an optimum design in order to facilitate all the mass transfer processes. In fact, an excessive amount of polymeric electrolyte causes the appearance of significance mass transfer limitations in the catalytic layer (Song et al., 2001). Finally, the own polymeric electrolyte has got also an important role, since the solubility of the gas in it is highly dependant on the cell operation conditions (Liu et al., 2006).

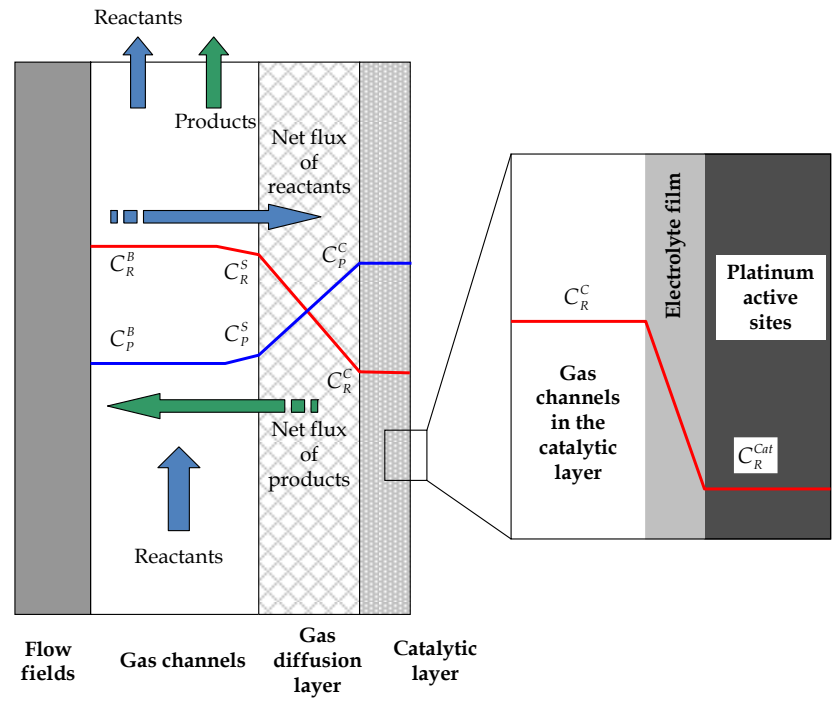

Fig. 2. Typical concentration profile inside a fuel cell

In the case of $\mathrm{H}_{3} \mathrm{PO}_{4}$ doped PBI-based high temperature PEMFC, compared to traditional Nafion $^{\circledR}$-based PEMFC, mass transport becomes slightly simpler since all the species are in vapour state, and therefore, flooding problems do not appear (Lobato et al., 2008b). However, this does not imply that mass transport processes are not important in terms of cell performance. Indeed, as previously commented, it is necessary an optimum transport of hydrogen and oxygen gas across the gas diffusion layer. Moreover, the removal of the water vapour generated in the cathode must be effective. In the catalytic layer of this type of fuel cells, phosphoric acid is present in order to provide a protons pathway for their migration, and hence, oxygen and hydrogen must diffuse through this thin electrolyte layer. Oxygen solubility in phosphoric acid has been reported to be low, compared to, for example, Nafion ${ }^{\circledR}$ (Mamlouk et al., 2010), which also results in an extra-limitation in terms of mass transfer within the catalytic layer.

\section{The role of the gas diffusion layer in high temperature PEMFC}

The membrane-electrode-assembly of a phosphoric acid doped PBI-based PEMFC is similar to traditional low temperature Nafion ${ }^{\circledR}$-based PEMFC, i.e., is formed by the membrane, and the electrodes. The electrodes, at the same time, are divided into two layers, the catalytic one, and the gas diffusion layer. The gas diffusion layer in high temperature PEM fuel cells must fulfil the following purposes (Benziger et al., 2005; Mathias et al., 2003; Williams et al., 2004): 
- Good transport properties, for a uniform distribution of the reactants across the electrode surface.

- High electronic conductivity to allow the transient of electrons between the catalytic layer and the bipolar/monopolar plate.

- Good mechanical resistance, since this layer is the support of the catalytic one.

- Good removal capacity of the water vapour produced in the cathode.

The GDL is formed by a carbonaceous support, generally carbon cloth or carbon fibre paper (Han et al., 2008), relatively rigid, macroporous, and highly conductive (Cindrella et al., 2009). Generally, this carbon support is wet-proofed with a certain amount of Teflon, which assists in an effective water management, and provides a pathway for the access of the reactant gases when massive amounts of water are being generated in the cathode (Park et al., 2004). Also, this amount of Teflon helps to keep the mechanical integrity of the gas diffusion layer during the hot pressing procedure used to prepare the membrane-electrodeassembly (MEA) (Lobato et al., 2008b).

In some cases, a second layer is incorporated to the GDL design, the microporous layer. As previously commented, this layer is formed by carbon black (Vulcan XC-72R, Ketjen Black, Acetylene Black...) (Antolini et al., 2002), and a certain amount of a polymeric binder (generally Teflon) (Carrete el al., 2001; Mathias et al., 2003). Both components, along with an appropriate solvent (generally non-toxic, e.g., isopropyl alcohol, water, ethylene glycol...) (Carrete et al., 2001) is generally deposited by forming a thick ink, and applied by different techniques, filtration, with the aid of an aerograph, tape-casting, etc. The properties of the ink and deposition method influence on the final mass transport properties of this layer (Cindrella et al., 2009; Mathias et al., 2003). The composition of this layer makes it have a microporous nature, with the following advantages:

- Uniform current distribution between the catalyst layer and the carbonaceous support, due to a more intimate contact between the layers.

- Avoid the penetration of catalyst particles in the carbon support, which would be located too far away from the membrane-electrode boundary, where most efficiently evolve the electrochemical reactions (Seland et al., 2006).

Figure 3 shows a schematic structure of a general electrode (including MPL) for a high temperature phosphoric acid doped PBI-based PEMFC.

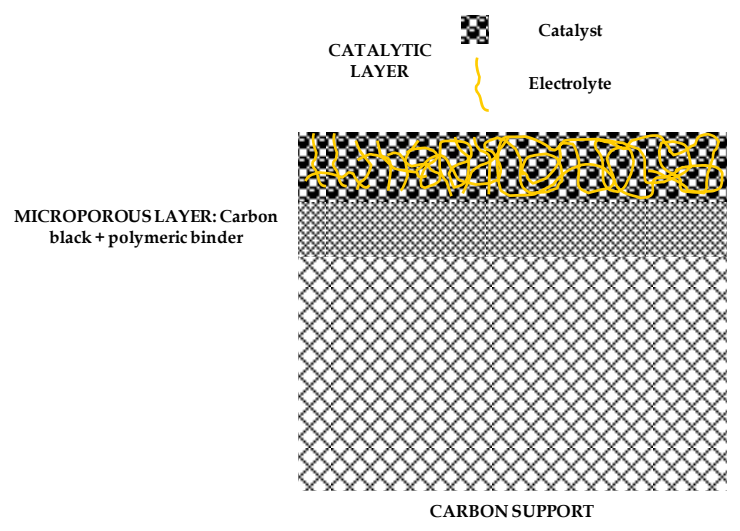

Fig. 3. Schematic general structure of an electrode with microporous layer 
Therefore, in order to maximize the cell performance not only in terms of mass transfer, but in global terms, it is logically necessary to have an optimum gas diffusion layer structure, both in terms of the carbon support, and microporous layer. For this purpose, physical and electrochemical characterisation of the gas diffusion layer is performed, as it will be shown in the following sections.

\subsection{The carbon support. Influence of the Teflon percentage}

Carbon cloth, carbon fibre papers, or carbon felt are different options to be used as carbonaceous support in PEM Fuel Cells. Although any of them presents different advantages and disadvantages, carbon fibre papers is interesting in terms of robustness and mechanical reliability. This carbon paper is supplied by the Japanese company Toray Industries Inc., with different thickness 90, 170, 260 and $350 \mu \mathrm{m}$ ), and also with the possibility of different levels of wet-proofing (Teflon percentage on the basis of the carbon paper weight). If the MEA is prepared by hot pressing, thick carbon supports are more suitable in terms of mechanical integrity. For this material, a very interesting parameter to be analyzed is the influence of the Teflon on its physical properties, and on the electrochemical performance of the subsequent prepared electrode.

\subsubsection{Physical characterisation}

Next, some results of useful physical characterization techniques are presented. The physical parameters next evaluated have got a strong influence on the mass transport properties of the GDL, and therefore, on the cell performance in terms of mass transfer parameters (limiting current density).

A typical pore size distribution of the carbon fibre paper (Toray Graphite Paper, TGPH-120, $350 \mu \mathrm{m}$ ) obtained from $\mathrm{Hg}$ porosimetry for the different Teflon percentage is shown in Figure 4 .

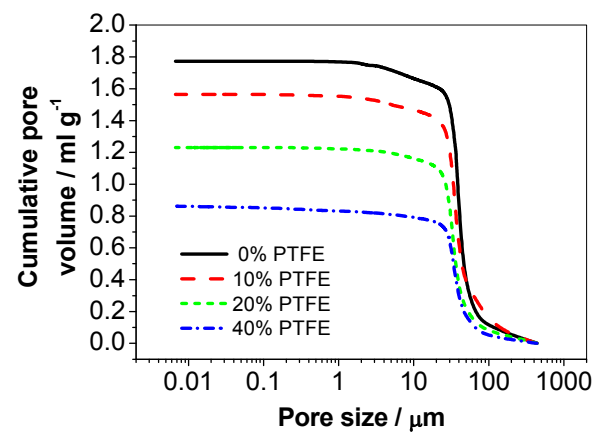

(a)

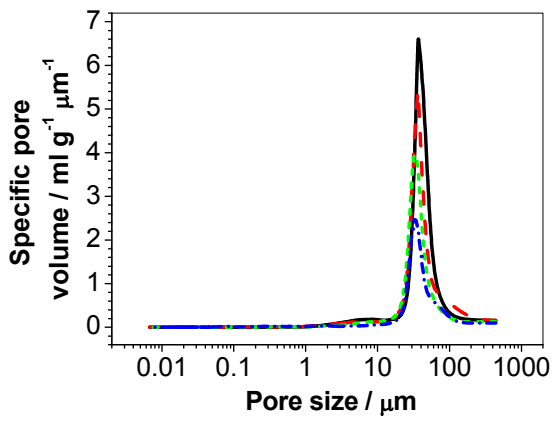

(b)

Fig. 4. (a) Cumulative, and (b) Specifical pore size volume for the differente Teflon percentage in the carbon fibre paper (TGPH-120) (Lobato et al., 2008b, with permission of Kluwer Academics)

As it can be seen, the carbon support present a macroporous structure, with most of the pores in the range of 30-70 $\mu \mathrm{m}$. Moreover, Teflon content reduces the macroporosity of the carbon paper. From the pore size distribution, other interesting parameters can be 
evaluated, such as the overall porosity, the mean pore size, and the tortuosity. Table 1 collects the corresponding values.

\begin{tabular}{|c|c|c|c|}
\hline PTFE content $/ \mathbf{\%}$ & Porosity / $\%$ & Mean pore diameter $/ \boldsymbol{\mu m}$ & Tortuosity \\
\hline 0 & 76.3 & 39.4 & 2.932 \\
\hline 10 & 73.9 & 36.7 & 3.363 \\
\hline 20 & 69.6 & 33.9 & 3.582 \\
\hline 40 & 61.6 & 31.6 & 4.377 \\
\hline
\end{tabular}

Table 1. Overall porosity, mean pore size and tortuosity of the carbon support for the different Teflon loading percentage (Lobato et al., 2008b, with permission of Kluwer Academics)

As expected from the pore size distribution curves, porosity and mean pore size diminishes with the increase in the Teflon content, whereas the tortuosity increases with the Teflon content. Porosity and tortuosity are important parameters, since they directly influence on the effective diffusion coefficient (Williams et al., 2004), according to Equation 1.

$$
\mathrm{D}_{\text {eff }}=\mathrm{D} \cdot \frac{\varepsilon}{\tau}
$$

Scanning electron microscopy is also a very useful tool in order to visualize the microstructure of the gas diffusion layer. Figure 5 displays the micrographs of the Toray Graphite Papers for the different Teflon percentage.

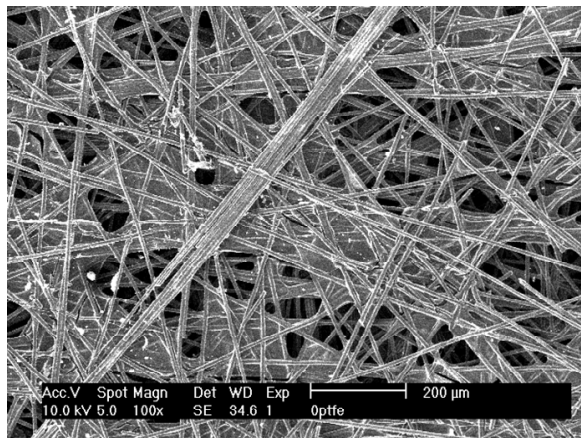

(a)

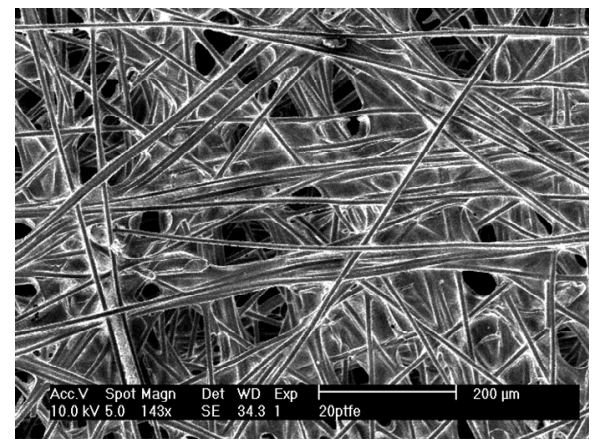

(b)

Fig. 5. SEM micrographs of (a) Plain carbon fibre paper, (b) $20 \%$ wet-proofed carbon paper (Lobato et al., 2008b, with permission of Kluwer Academics)

As it can be seen, appreciable differences appear between both carbon papers. When Teflon is applied, a large number of macropores are closed by the presence of the polymer binder, reflecting the previous results obtained by $\mathrm{Hg}$ porosimetry. Teflon occupies parts of the macropores between the carbon fibres.

Gas diffusion layer permeability is another interesting parameter. Although this parameter is related with convectional processes, it can give us a rough idea about the transport properties of the gas diffusion layer. Figure 6 shows the gases $\left(\mathrm{H}_{2}, \mathrm{O}_{2}\right.$, air and water vapour) permeability of the different carbon support. For its calculation, Equation 2 must be used. 


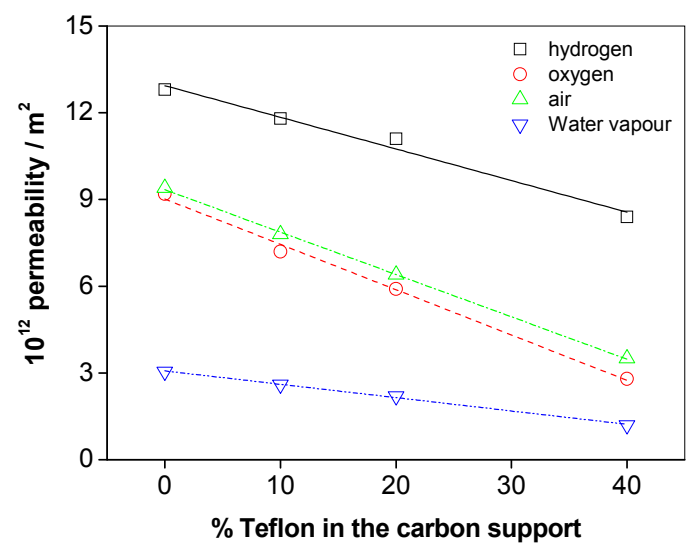

Fig. 6. Gases permeability of the carbon support for different Teflon contents

$$
\mathrm{K}=\frac{\mathrm{Q} \cdot \mu \cdot \mathrm{L}}{\mathrm{S} \cdot \Delta \mathrm{P}}
$$

As expected, gas (or water vapour) permeability reduces with the Teflon content due to the blockage of part of the macroporosity by the Teflon (Prasanna et al., 2004a; Prasanna et al., 2004b; Soler et al., 2003; Williams et al., 2004). It is especially significant the value of the water vapour permeability, since in this type of fuel cell, water product will be in this state.

Gases permeability follows the expected trend according to their molecular size. Hydrogen permeates easily through the carbon support, whereas oxygen and air have got a more limited access. This, as will be later shown, reflects on the fuel cell performance, where hydrogen mass transport limitations are less noticeable than in the case of oxygen. In the case of water vapour, the fashion is broken, but this might be due to the vapour nature compared to gases.

\subsubsection{Electrochemical behaviour}

The electrochemical behaviour of a fuel cell is mainly defined by the polarization curves. As it was previously described, three main regions appear, each one related to different processes governing the performance. In this particular case, mass transport properties of the carbon support will mainly influence the cell performance at the highest current densities, where large amounts of gas reactants are claimed, and massive amounts of water vapour have to be released from the cell. In order to assist for the interpretation of the fuel cell results, a semi-empirical model (Linares, 2010) was developed, which includes kinetic, ohmic, and mass transport parameters (Equation 3).

$$
E=E_{0}^{\prime}-b \log j-R_{e} j+b \ln \left(1-\frac{j}{j_{O L}}\right)-R_{p o l} \cdot j \cdot\left(\frac{j_{H L}}{j_{H L}-j}\right)^{1 / 2}
$$


Parameter $\mathrm{E}$ is the cell voltage, $\mathrm{E}_{0}$ is the open circuit voltage, $\mathrm{b}$ is the Tafel slope, being these two latter related to the mechanism of the oxygen reduction reaction, $R_{e}$ is the ohmic resistance of the system, $j$ is the experimental current density, joL is the limiting cathode current density, $\mathrm{R}_{\mathrm{pol}}$ is the lineal polarization resistance of the hydrogen oxidation reaction, and $\mathrm{j}_{\mathrm{HL}}$ is the limiting anode current density.

Impedance can be also an interesting tool to identify the appearance of mass transfer limitations associated with the gas diffusion layer (Bultel et al., 2005; Ciurenau et al., 2001; Ciurenau et al., 2003; Springer et al., 1996; Paganin et al., 1998). In general, it is admitted that the appearance at low cell voltage (high current densities) of a second loop in the typical one-loop spectrum of a fuel cell (Yuan et al., 2007) is due to mass transfer limitations in the gas diffusion layer.

Influence of the percentage of Teflon in the carbon support was studied for both the anode and the cathode. In the case of the cathode, results for reduced stoichometries and air were subjected to study, along with the impedance response of the cell when air was used. In the case of hydrogen, it was analyzed the performance under a limited $\mathrm{H}_{2}$ stoichometry.

i) The carbon support in the cathode

Figure 7 shows the cell performance for the 10-20-40\% Teflon in the carbon support. Points represent the experimental data, whilst lines represent the fitting to the semi-empirical model.

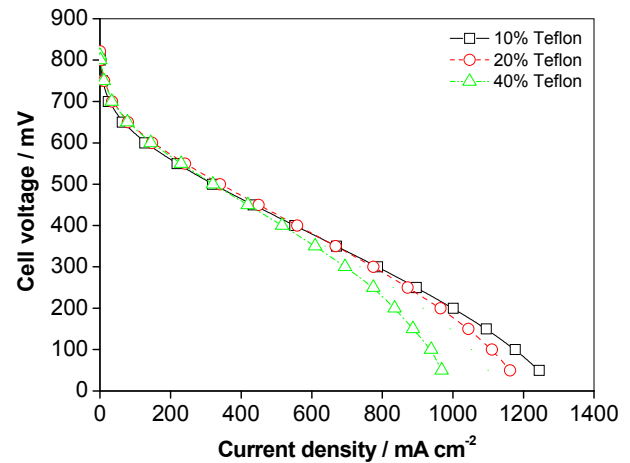

(a)

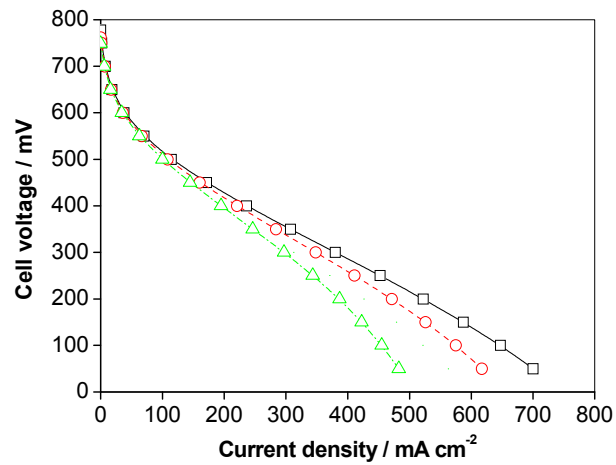

(b)

Fig. 7. Fuel Cell performance for the different Teflon percentage in the carbon support: (a) Oxygen stoichometry at $1 \mathrm{~A} \mathrm{~cm}^{-2}=1,5,(\mathrm{~b})$ Air stoichometry at $1 \mathrm{~A} \mathrm{~cm}^{-2}=4$

As it can be seen, the presence of a large amount of Teflon in the carbon support diminishes the cell performance, especially at the highest current densities. The corresponding values of the limiting current density are collected in Table 2 . They resemble to the fashion of a more limited transport properties of the carbon support the higher is the Teflon percentage. On the other hand, it can be seen the detrimental effect of substituting oxygen by air. Reduction of the oxygen partial pressure dramatically influences the cell performance.

Figure 8 shows the impedance spectra of the cell under air operation, at a cell voltage of 300 $\mathrm{mV}$. Points represent the experimental data, whereas lines show the fitting to the equivalent circuit. In order to help to split the contribution of each process, a equivalent circuit (Boukamp, 1986) consisting of a series association of one ohmic resistance, one parallel mini- 
circuit constant phase element and resistance, related to the charge transfer processes (kinetic), and another parallel mini-circuit constant phase element and resistance, associated to mass transfer, is proposed [see Fig. 7(a)]. Table 2 also collects the values of the corresponding mass transfer resistances.

As it can be seen, and concomitantly to fuel cell results, impedance spectra show how the total resistance of the system increases the higher is the Teflon percentage. More concretely, mass transfer resistance calculated from the fitting of the experimental data to the equivalent circuit confirms this notorious increase in $\mathrm{R}_{\mathrm{mt}}$. In consequence, a low Teflon percentage in the carbon support is desirable in order to favour the mass transport processes. A non wet-proofed carbon paper may be utilized; however, mechanical integrity of the electrode may be risked, due to the weakness of this particular carbon paper (Lobato et al., 2008b).

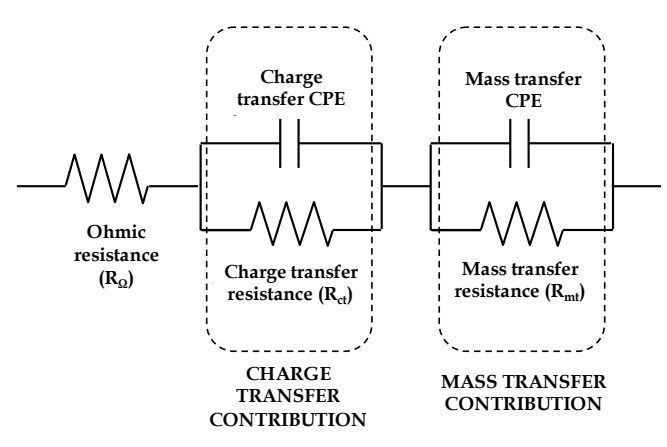

(a)

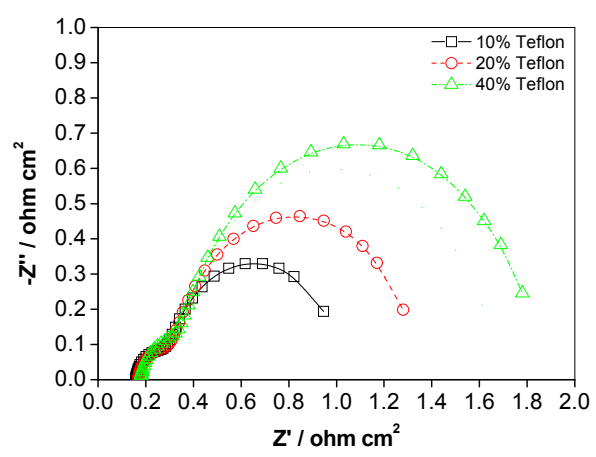

(b)

Fig. 8. (a) Equivalent circuit for the fitting of the experimental impedance data, (b) Impedance spectra of the electrodes with different Teflon percentages

\begin{tabular}{|c|c|c|c|}
\hline PTFE content $/$ \% & joL,oxygen $/ \mathbf{m A ~} \mathbf{~ c m}^{-2}$ & joL,air $/ \mathbf{~ m A ~} \mathbf{~ c m}^{-2}$ & $\mathbf{R}_{\mathbf{m t}} / \mathbf{~ o h m ~} \mathbf{~ c m}^{\mathbf{2}}$ \\
\hline 10 & $1,418.9$ & 952.8 & 0.744 \\
\hline 20 & $1,272.1$ & 786.6 & 1.041 \\
\hline 40 & $1,029.8$ & 562.2 & 1.502 \\
\hline
\end{tabular}

Table 2. Limiting current densities for oxygen and air operation, and the mass transfer resistance for the different Teflon percentage in the carbon support.

ii) The carbon support in the anode

Figure 9 shows the fuel cell performance for the different Teflon loaded carbon supports.

As it can be seen for all the Teflon percentages in the carbon support, the cell performances are almost equal, and just tiny differences are observed when achieving the limiting current density conditions. This demonstrates that the controlling reaction in high temperature PBIbased PEMFC is the cathodic one (Jalani et al., 2006). Differences just appear at limiting conditions, as it was also observed by Pan et al. (Pan et al., 2007). Table 3 collects the corresponding values for the hydrogen mass transfer. 


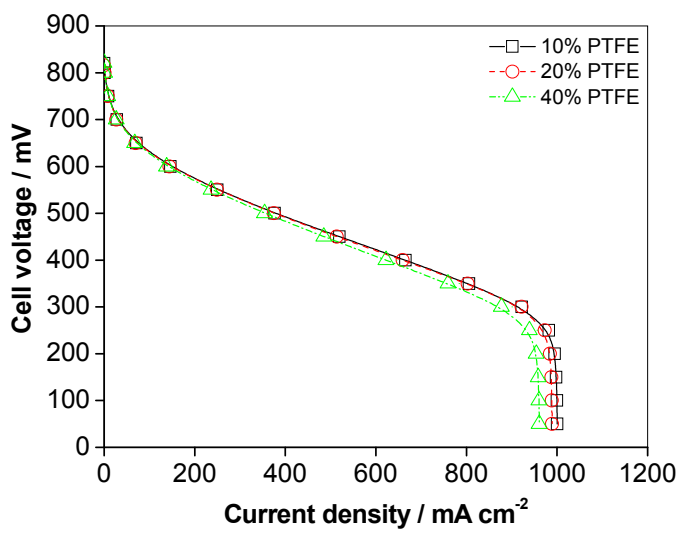

Fig. 9. Influence of the Teflon percentage on the cell performance. Hydrogen stoichometry at $1 \mathrm{~A} \mathrm{~cm}^{-2}=1$ (Points: experimental data; lines: fitting to the model)

Values in Table 3 confirm the expected reduction in the limiting current density due to the most limited hydrogen transport from the gas channels to the catalytic layer. However, it is noticeable that these values are very close to the stoichometric ones, so that, in principle, hydrogen transport in the carbon support, unless very limited hydrogen flow, is not a limiting factor in the performance of a High Temperature PEMFC.

\begin{tabular}{|c|c|}
\hline PTFE content $\mathbf{~} \mathbf{0}$ & $\mathbf{j}_{\mathrm{HL}, \text { hydrogen }} / \mathbf{m A ~ \mathbf { ~ c m } ^ { - 2 }}$ \\
\hline 10 & $1,000.9$ \\
\hline 20 & 990.1 \\
\hline 40 & 961.9 \\
\hline
\end{tabular}

Table 3. Limiting current density for the hydrogen oxidation for the different Teflon percentages of the carbon support

\subsection{The microporous layer}

As it was previously commented, the microporous layer is deposited on the carbon support, and is formed by carbon black and a polymer binder, in this case, Teflon. As in the case of the carbon support, two types of studies were carried out:

- Physical characterisation. Measurements of the pore size distribution, overall porosity, mean pore size, tortuosity, and finally, the permeability to the different reactants and water vapour product.

- Electrochemical behaviour. Evaluation of the cell performance under restricted stoichometries. Impedance spectra are also used in order to assist for the interpretation of the mass transfer influence on the fuel cell results.

Physical characterisation was carried out on the complete gas diffusion layer, i.e., the sum of the carbon support (10\% Teflon loaded TGPH-120) and the microporous layer. In the case of the electrochemical studies, actual electrodes were tested in the fuel cell. Beneficial effects of the microporous layer are shown in the following results. 


\subsubsection{Influence of the Teflon percentage in the microporous layer}

For this study, microporous layers with a carbon content of $1 \mathrm{mg} \mathrm{cm}^{-2}$ were prepared, varying, on a total weight base, the percentage of Teflon (10, 20, 40 and 60\%). Lower Teflon percentage could not be used, because they attempted against the integrity of the MPL.

\section{a) Physical characterisation}

Figure 10 displays the pore size distribution for the gas diffusion layer with different Teflon percentage in the microporous layer. Specific pore size distribution is shown in the macroporous and microporous region, for a better visualization of the effect of the inclusion of the microporous layer in the carbon support, and the effect of the Teflon percentage in the MPL.

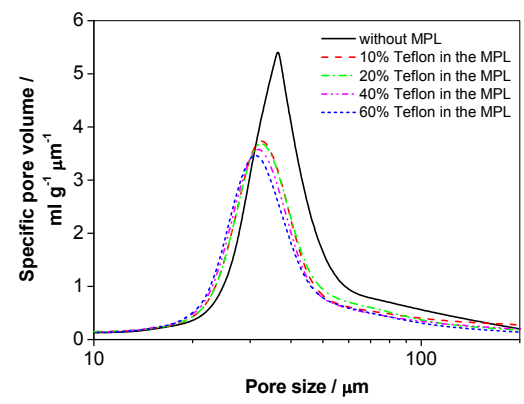

(a)

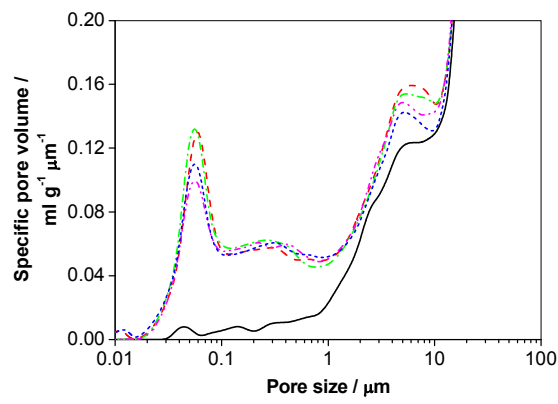

(b)

Fig. 10. Specific pore volume for the GDLs with different Teflon percentage in the MPL in: (a) the macroporous region, and (b) in the microporous layer.

As it can be seen, the presence of the MPL reduces the amount of macropores in the carbon support. Part of the microporous layer penetrates inside the carbon support, partially closing its macroporous structure. On the other hand, the increase in the Teflon percentage in the MPL hardly affects the macroporous structure. In the case of the microporous, the presence of the MPL generates microporosity in the GDL. This result diminished with the increase in the binder percentage. The Teflon occupies part of the microporous structure of the MPL. Table 4 displays the values of the overall porosity, mean pore size, and tortuosity of the GDL, extracted from the pore size distribution, for the different Teflon-loaded MPL.

As it can be seen, the overall porosity and mean pore size decrease with the Teflon content in the MPL, and further does with the inclusion of the MPL. Comparing with the Teflon percentage in the carbon support, the diminution is lower, since in this case the microporous structure is only affected, which has a lower weight on the global structure of the complete GDL. In the case of the tortuosity, it can be seen a noticeable increase with the inclusion of the MPL, making more difficult the fluid transit.

\begin{tabular}{|c|c|c|c|}
\hline PTFE content $/ \%$ & Porosity / $\%$ & Mean pore diameter $/ \boldsymbol{\mu m}$ & Tortuosity \\
\hline Without MPL & 73.9 & 36.69 & 3.363 \\
\hline 0 & 70.6 & 34.23 & 3.795 \\
\hline 10 & 70.2 & 34.02 & 3.871 \\
\hline 20 & 69.4 & 33.81 & 3.940 \\
\hline 40 & 68.9 & 33.63 & 4.130 \\
\hline
\end{tabular}

Table 4. Values of the overall porosity, mean pore size diameter and tortuosity for the GDLs with different Teflon loaded MPL 
Gases/water vapour permeability is shown in Figure 11 for the GDL with different Teflon percentage of the MPL.

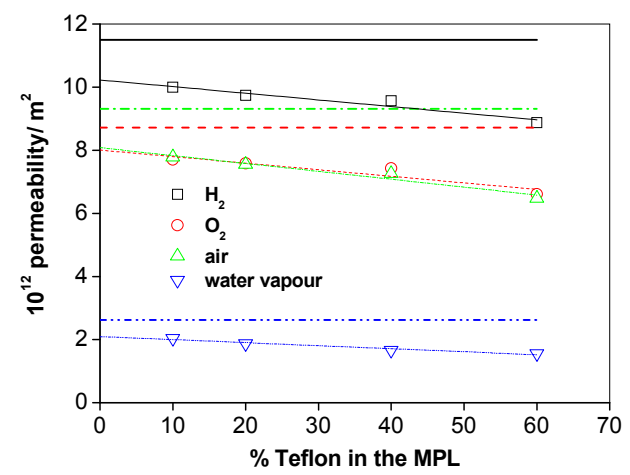

Fig. 11. Gases and water vapour permeability of the GDLs with different Teflon percentage in the MPL (horizontal lines represent the carbon support permeability)

As it can be observed, the gases/water vapour permeability diminishes with the Teflon content in the MPL. Logically, the occlusion of part of the microporous makes more difficult the transient of the gases through the GDL, and therefore, mass transfer becomes more impeded for high Teflon percentages in the MPL. As in the case of the carbon support, the values of the gases permeability for each gas are in the line of its molecular size, except for the case of water vapour.

Therefore, in terms of mass transfer physical related properties, the use of a low percentage of Teflon in the MPL appeared to be beneficial. High porosity and permeability, and low tortuosity can be achieved under these conditions. On the other hand, these results also suggest the suitability of uniquely the carbon support in the MPL, even though these preliminary results must be confirmed by the fuel cells one.

\section{b) Electrochemical behaviour}

b.i) The Teflon percentage in the cathodic MPL

Figure 12 shows the variation of the cell performance for the GDLs with different Teflon percentage in the MPL. Points correspond to the experimental data, whereas lines show the fitting of these data to the semi-empirical model.

First of all, it is important to mention the positive effect that has got the inclusion of the MPL in the cell performance. This result can be explained taking into account one of the missions of the MPL: avoid the penetration of the catalyst particle in the carbon support. In the pore size distribution, it has been observed that part of the MPL penetrates into the carbon support, blocking part of the macroporosity. MPL and catalytic layer have a similar pore size distribution (same carbon black support), and therefore this latter penetrates into the carbon support if no MPL is used (Lobato et al., 2010b). Secondly, cell performance clearly worsens with an increase of the Teflon content. Unlike the carbon support, in this case the overall cell performance seems to result affected by an excess of Teflon binder, as Prasanna et al. (Prasanna et al., 2004a) also observed for Nafion ${ }^{\circledR}$-based PEMFC. Therefore, the MPL 
does not only have influence in terms of mass transfer limitations, but in kinetic and ohmic ones due to an excess of insulator material. Table 5 collects the values arisen from the fitting of the experimental data to the semi-empirical model.

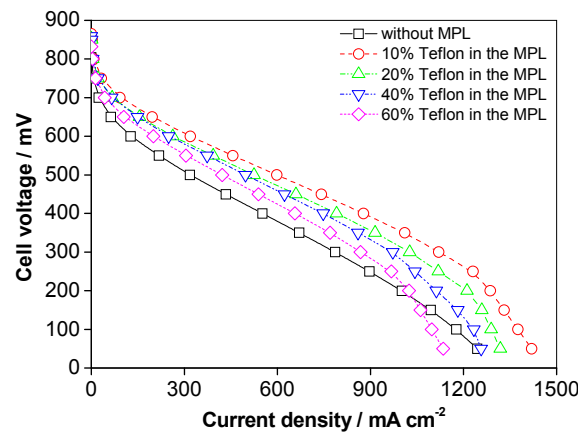

(a)

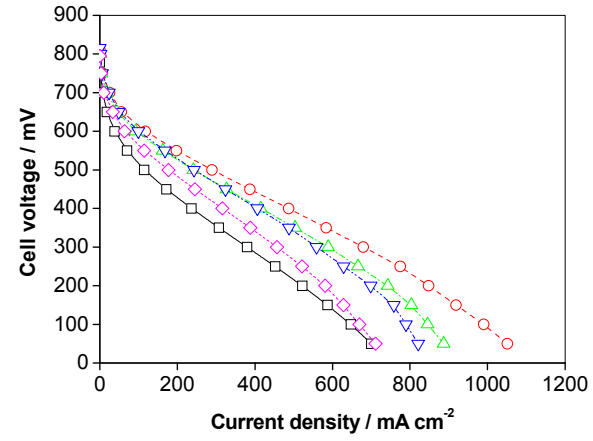

(b)

Fig. 12. Cell performance of the electrodes prepared with different Teflon percentage in the MPL, (a) Oxygen stoichometry at $1 \mathrm{~A} \mathrm{~cm}^{-2}=1,5$, (b) Air stoichometry at $1 \mathrm{~A} \mathrm{~cm}^{-2}=4$

\begin{tabular}{|c|c|c|c|}
\hline PTFE content $\mathbf{~ \% ~}$ & joL,oxygen $/ \mathbf{~} \mathbf{A} \mathbf{~ c m}^{-2}$ & joL,air $/ \mathbf{~} \mathbf{A ~} \mathbf{~ m}^{-2}$ & $\mathbf{R}_{\mathbf{m t}} / \mathbf{~ o h m ~} \mathbf{~ c m}^{\mathbf{2}}$ \\
\hline Without MPL & $1,418.9$ & 952.8 & 0.744 \\
\hline 10 & $1,477.6$ & $1,115.4$ & 0.430 \\
\hline 20 & $1,400.5$ & $1,005.1$ & 0.622 \\
\hline 40 & $1,320.7$ & 922.5 & 0.761 \\
\hline 60 & $1,240.2$ & 790.3 & 0.995 \\
\hline
\end{tabular}

Table 5. Limiting current densities for oxygen and air operation, and the mass transfer resistance for the different Teflon percentage in the MPL

Model values confirm the experimental results and show how the $10 \%$ Teflon loaded MPL presents the maximum value of the limiting current density, both in the case of oxygen with a reduced stoichometry, and air. Figure 13 shows the corresponding impedance spectra at $300 \mathrm{mV}$ when the cell was operated with air. Values of the mass transfer resistance after fitting the experimental data to the equivalent circuit are collected in Table 5.

Impedance spectra show the benefits of the inclusion of the MPL in the electrode design by the reduction of the global resistance of the cell. Moreover, this resistance attains its lowest values when the MPL is loaded with $10 \%$ Teflon. Higher loadings reflect higher mass transfer limitations, as the values of the $R_{m t}$ displays. Consequently, the MPL must be included for high temperature PEMFC electrodes, since all the cell processes are enhanced, despite the decrease in the mass transfer parameters when added. On the other hand, a low Teflon percentage must be used in terms of global performance.

b.ii) The Teflon percentage in the anodic MPL

Figure 14 shows the influence of the Teflon percentage of the MPL in different GDLs. 


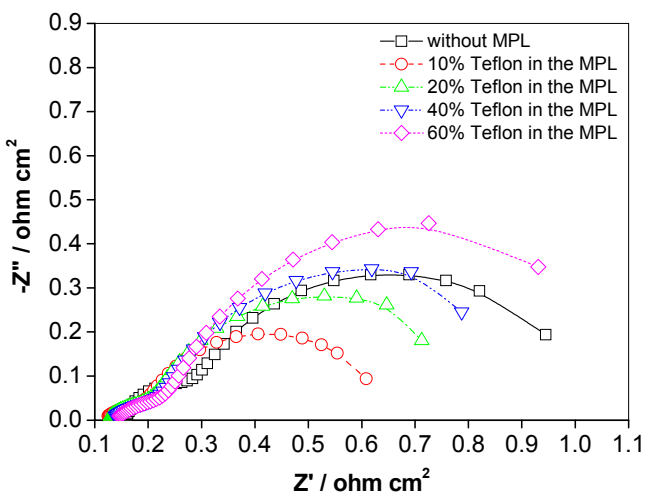

Fig. 13. Impedance spectra of the cell when electrodes with different Teflon percentage in the MPL were used

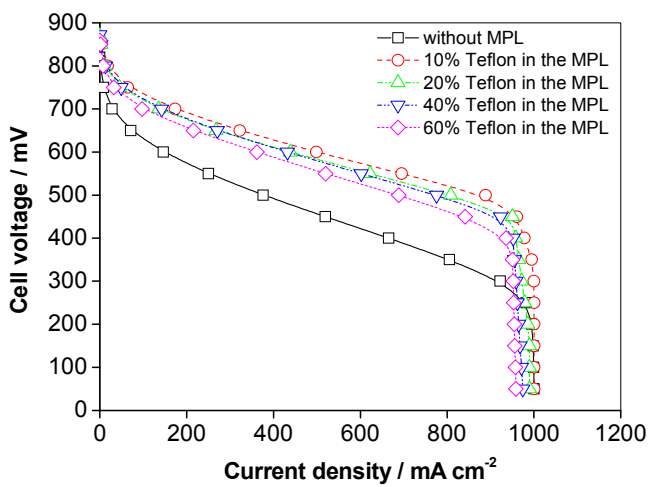

Fig. 14. Influence of the Teflon percentage in the MPL on the cell performance. Hydrogen stoichometry at $1 \mathrm{~A} \mathrm{~cm}^{-2}=1$ (Points: experimental data; lines: fitting to the model)

As it can be observed, the influence of the Teflon percentage in the MPL on the cell performance, as in the case of the carbon support, appears almost at the values corresponding to the limiting current density. However, a close look at the curves shows that the limiting current densities slightly diminishes as the Teflon percentage in the MPL increases, reflecting the higher limitation of the mass transport when a less porous or permeable GDL is used. In order to assist for interpretation of the fuel cell results, values of the hydrogen limiting current density are collected in Table 6.

Values in Table 6 display the benefits of using an open GDL. In fact, the highest hydrogen limiting current density was obtained for the MPL free GDL, even though the protection of the catalytic layer plays a more important role in terms of global performance (lower performance in almost the whole range of current densities). Therefore, in terms of global performance, it is also advisable to use a MPL with a low Teflon percentage. 


\begin{tabular}{|c|c|}
\hline PTFE content $\mathbf{~} \mathbf{0}$ & $\mathbf{j}_{\text {HL,hydrogen }} / \mathbf{~} \mathbf{A} \mathbf{~ c m}^{-2}$ \\
\hline Without MPL & $1.000,8$ \\
\hline 10 & $1,000.4$ \\
\hline 20 & 990.2 \\
\hline 40 & 980.9 \\
\hline 60 & 964.9 \\
\hline
\end{tabular}

Table 6. Limiting current density for the hydrogen oxidation for the different Teflon percentages of the MPL

\subsubsection{Influence of the carbon content in the microporous layer}

For this study, microporous layers with a Teflon percentage of $10 \%$ were prepared, on a total weight base, varying the carbon loading $\left(0.5,1,2\right.$ and $\left.4 \mathrm{mg} \mathrm{cm}^{-2}\right)$.

\section{a) Physical characterisation}

Figure 15 shows the pore size distribution of the gas diffusion layer for the different carbon loadings in the MPL, along with the carbon support. Results are shown focusing on the macroporous and microporous regions.

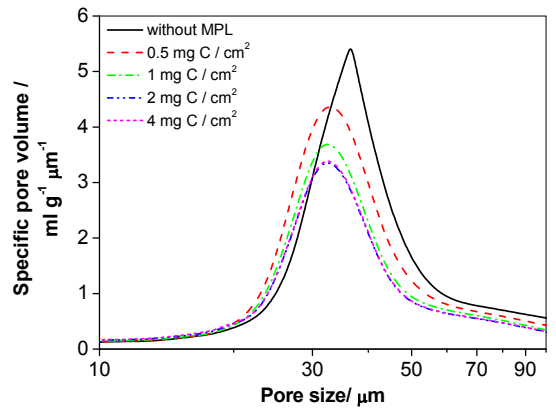

(a)

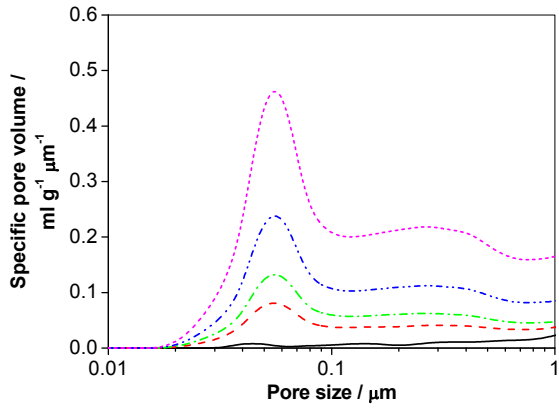

(b)

Fig. 15. Specific pore volume for the GDLs with different carbon loadings in the MPL in: (a) the macroporous region, and (b) in the microporous layer (Lobato et al., 2010, with permission of Wiley Interscience)

As it can be observed, the macroporosity of the GDL diminishes with the addition of more carbon to the MPL. As previously commented for the Teflon percentage, part of the MPL will penetrate inside the macroporous carbon support, and therefore, will occlude part of the macropores. Macroporosity decreases until a carbon loading of $2 \mathrm{mg} \mathrm{cm}^{-2}$. Above this value, no more MPL carbon particles seem to penetrate into the carbon support, and therefore, the MPL is fully fulfilling its protective role since it is expected that no catalytic particle will penetrate inside the carbon support. Contrarily, the microporous region increases with the carbon content of the MPL. Logically, more microporosity is introduced in the system the higher is the carbon content (Park et al., 2006).

Overall porosity, mean pore size and tortuosity of the GDL with different carbon loading in the MPL can be estimated from the pore size distribution. The corresponding values are collected in Table 7. 


\begin{tabular}{|c|c|c|c|}
\hline Carbon loading/ $\mathbf{m g ~ \mathbf { ~ c m } ^ { - 2 }}$ & Porosity / $/ \mathbf{0}$ & Mean pore diameter $/ \boldsymbol{\mu m}$ & Tortuosity \\
\hline Without MPL & 73.9 & 36.69 & 3.363 \\
\hline 0.5 & 72.2 & 34.32 & 3.502 \\
\hline 1 & 72.2 & 33.23 & 3.717 \\
\hline 2 & 69.2 & 32.10 & 4.152 \\
\hline 4 & 67 & 30.50 & 4.620 \\
\hline
\end{tabular}

Table 7. Values of the overall porosity, mean pore size diameter and tortuosity for the GDLs with different carbon loadings MPL

As it can be seen, the overall porosity and the mean pore size of the GDL decrease with the carbon loading. The diminution of the macroporosity and the increase of the microporosity of the GDL explain the reduction of the overall porosity and mean pore size. In the case of the tortuosity, the higher is the carbon loading, the thicker the MPL layer becomes, making more difficult the access of the gases to the catalytic layer.

Gases/water vapour permeability for the GDLs with different carbon loading in the MPL are shown in Figure 16.

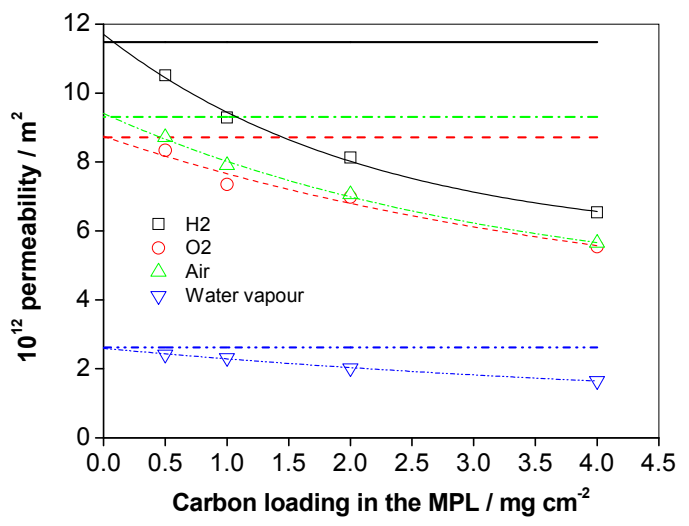

Fig. 16. Gases and water vapour permeability of the GDLs with different carbon loadings in the MPL (horizontal lines represent the carbon support permeability)

As it can be seen, gases/water vapour permeability decreases with the carbon loading in the GDL. This is an effect of the reduction of the macroporosity, and the increase in the microporosity, which makes more difficult the transport of the gases reactant, and the water vapour through the GDL (Wang et al., 2006). On the other hand, the decay in the permeability becomes less noticeable the higher is the carbon loading in the MPL. This agrees with the previously mentioned fact that a lower amount of carbon particles from the MPL penetrates in the carbon support, so that the results reflect the effect of the increase in the microporosity. As in the previous cases, the molecular size of the gases determines the values of the gas permeability, except for the case of the extensively commented water vapour.

As in the case of the influence of the Teflon percentage in the MPL, the simplest GDL, without microporous layer, seems to be the most adequate disposition in terms of mass 
transport. However, in terms of fuel cell performance, other factors, as next shown, have to be taken into account. As it has been commented throughout this chapter, the MPL fulfils a very important protective role of the catalytic layer.

b) Electrochemical behaviour

b.i) The carbon loading in the cathodic MPL

Figure 17 shows the variation of the cell performance for the GDLs with different carbon loadings in the MPL. Points correspond to the experimental data, whereas lines show the fitting of these data to the semi-empirical model.

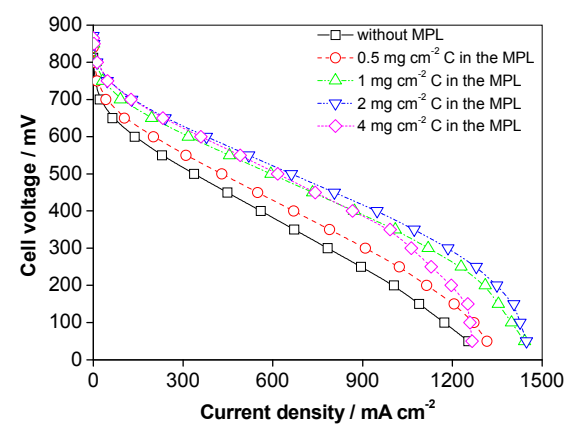

(a)

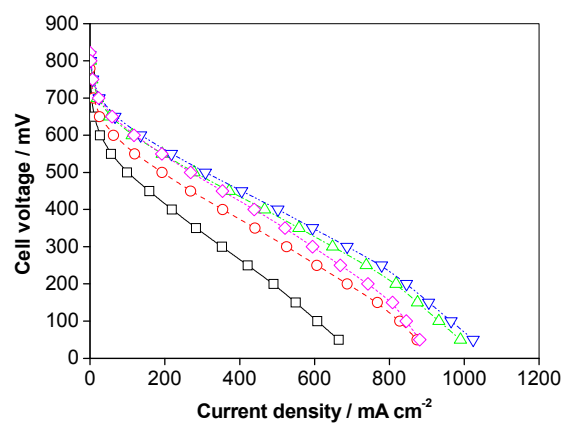

(b)

Fig. 17. Cell performance of the electrodes prepared with different carbon loading in the MPL, (a) Oxygen stoichometry at $1 \mathrm{~A} \mathrm{~cm}^{-2}=1,5$, (b) Air stoichometry at $1 \mathrm{~A} \mathrm{~cm}^{-2}=4$ (Lobato et al., 2010b, with permission of Wiley Interscience)

The beneficial influence of the inclusion of the MPL in the electrode structure can be more clearly seen in these results. Cell performance increases with the addition of a larger carbon amount, due to the greater protection of the MPL, until a value of $2 \mathrm{mg} \mathrm{cm}^{-2}$. At this value, the MPL avoids the complete penetration of catalyst particles inside the carbon support. This results is coincident with the pore size distribution ones, in which macroporosity does not decrease above $2 \mathrm{mg} \mathrm{cm}^{-2}$. On the other hand, when the carbon loading is too excessive, a drop in the cell performance can be observed. This can be ascribed to the increase in the MPL thickness, with the consequent increase in the mass transport limitations. Table 8 collects the values of the limiting current density arisen from the fitting of the experimental data to the semi-empirical model.

Values of the oxygen limiting current densities show the suitability of the $2 \mathrm{mg} \mathrm{cm}^{-2}$ carbon loading, despite the most limited mass transport characteristics of this GDL compared to lower carbon loaded ones. This again points up that the important role that plays the microporous layer in terms of protection of the catalytic layer, contributing to a global enhancement of the cell performance. Nonetheless, limiting current density values decreases for the $4 \mathrm{mg} \mathrm{cm}^{-2}$ carbon loading, due to more prominent mass transfer limitation when excessively thick GDL are used. Figure 18 shows the corresponding impedance spectra at $300 \mathrm{mV}$ when the cell was operated with air. Values of the mass transfer resistance after fitting the experimental data to the equivalent circuit are collected in Table 8. 


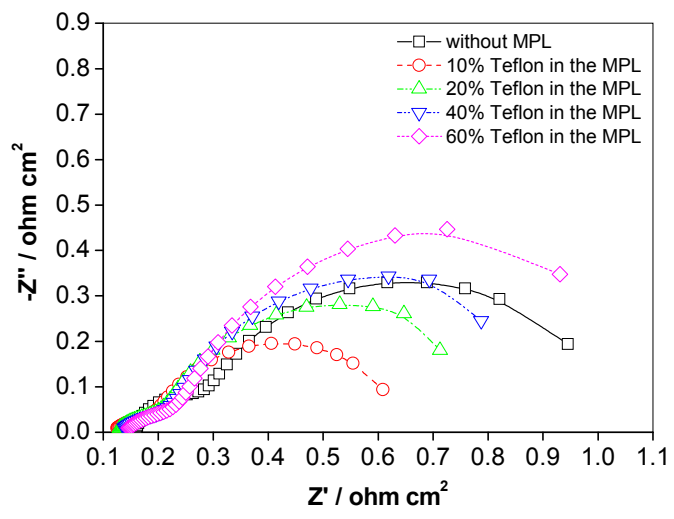

Fig. 18. Impedance spectra of the cell when electrodes with different carbon loading in the MPL were used (Lobato et al., 2010b, with permission of Wiley Interscience)

\begin{tabular}{|c|c|c|c|}
\hline Carbon loading/ $\mathrm{mg} \mathrm{cm}^{-2}$ & joL,oxygen $/ \mathrm{mA} \mathrm{cm}^{-2}$ & joL,air $/ \mathrm{mA} \mathrm{cm}^{-2}$ & $\mathbf{R}_{\mathrm{mt}} / \mathrm{ohm} \mathrm{cm} \mathbf{c}^{2}$ \\
\hline Without MPL & $1,418.9$ & 952.8 & 0.744 \\
\hline 0.5 & $1,431.3$ & $1,092.3$ & 0.621 \\
\hline 1 & $1,477.6$ & 1.115 .4 & 0.430 \\
\hline 2 & $1,479.2$ & 1.118 .3 & 0.408 \\
\hline 4 & $1,300.4$ & 980.3 & 0.565 \\
\hline
\end{tabular}

Table 8. Limiting current densities for oxygen and air operation, and the mass transfer resistance for the different Teflon percentage in the MPL

Impedance spectra confirm the suitability of the inclusion of the MPL, and the particular loading to use in order to obtain a good protection of the catalytic layer. Global cell resistance decreases with the carbon loading until a minimum value corresponding to $2 \mathrm{mg}$ $\mathrm{cm}^{-2}$ of carbon. If a higher carbon loading is applied, mass transfer resistance notably increases, showing more limitations in terms of gases/vapour transport, due to the excessive amount of carbon present in the MPL.

The influence of the carbon loading has demonstrated the importance of the addition of the MPL to the electrode design. Protection of the catalytic layer is fundamental in order to maximize the cell performance, and indeed, and according to the experimental results, it plays even a more important role than mass transfer characteristics of the GDL. However, if an excessive amount of carbon is added to the MPL, significant mass transport limitations appear, leading to an optimum carbon loading of $2 \mathrm{mg} \mathrm{cm}^{-2}$.

b.ii) The Teflon percentage in the anodic MPL

Figure 19 shows the influence of the Teflon percentage of the MPL in different GDLs.

As it can be observed, the influence of the carbon loading in the anodic MPL is more notorious than in the case of the cathode. However, it is visible the beneficial effect of the inclusion of the MPL, despite being at the anode. The carbon loading, in this case, slightly improves the global cell performance with an increase of the carbon loading, showing the best performances for 1 and $2 \mathrm{mg} \mathrm{cm}^{-2}$, and a decrease when the carbon loading was 
$4 \mathrm{mg} \mathrm{cm}-2$. Table 9 collects the values of the hydrogen limiting current density for the different carbon loaded MPL in the gas diffusion layer.

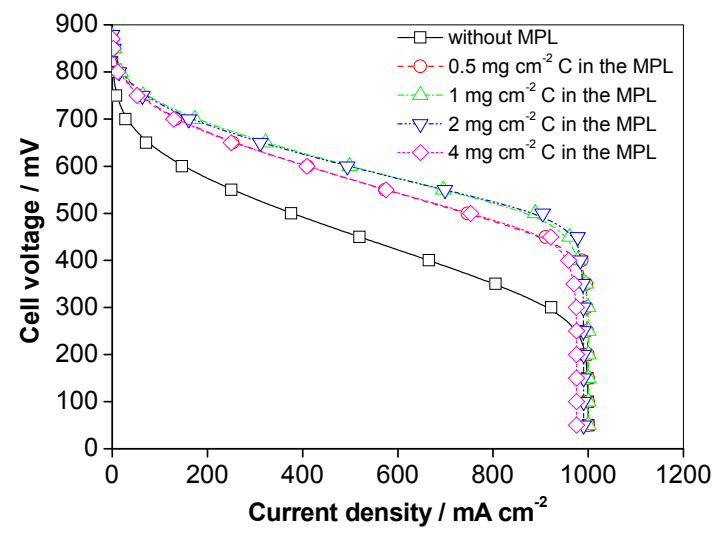

Fig. 19. Influence of the carbon loading in the MPL on the cell performance. Hydrogen stoichometry at $1 \mathrm{~A} \mathrm{~cm}^{-2}=1$ (Points: experimental data; lines: fitting to the model) (Lobato et al., 2010b, with permission of Wiley Interscience)

Values of the limiting current density are very similar for GDL without MPL, and with low loadings of carbon, demonstrating the suitability of these gas diffusion layers in terms of mass transport. Nevertheless, in the case of the carbon loading of 2 and $4 \mathrm{mg} \mathrm{cm}^{-2}$, the limiting current density decreases, due to the more impeded access of the hydrogen gas. However, as in the case of the study focused on the cathode, the optimum protective role of the MPL prescribes the use of a carbon loading of $2 \mathrm{mg} \mathrm{cm}^{-2}$, since hydrogen mass transfer limitations will only appear in case of the use of a very restricted stoichometry.

\begin{tabular}{|c|c|}
\hline Carbon loading/ $\mathrm{mg} \mathrm{cm}^{-2}$ & $\mathrm{j}_{\mathrm{HL}, \text { hydrogen }} / \mathrm{mA} \mathrm{cm}^{-2}$ \\
\hline Without MPL & $1.000,8$ \\
\hline 0.5 & $1,000.1$ \\
\hline 1 & $1,000.4$ \\
\hline 2 & 990.2 \\
\hline 4 & 975.3 \\
\hline
\end{tabular}

Table 9. Limiting current density for the hydrogen oxidation for the different carbon loading in the MPL

\section{Conclusions}

The gas diffusion layer plays an important role for High Temperature PBI-based PEMFC in terms of cell performance. Thus, it is desirable to have a carbonaceous support with a low Teflon content (10\% Teflon), in order to guarantee the mechanical stability of the membraneelectrode assembly, and have the maximum porosity and permeability, allowing the reduction of the mass transfer limitations. On the other hand, it is even more important the inclusion of a microporous layer in the design of the electrodes, since this protects the 
catalytic layer for penetrating within the macroporous carbon support, maximizing the electrochemically active area of the electrode. For this purpose, a carbon loading of $2 \mathrm{mg} \mathrm{cm}^{-2}$ is an optimum value. Besides, with this loading, the electrode presents the best mass transfer characteristics. Finally, the amount of polymer binding (Teflon) to add in this layer must be the minimum possible one (10\% Teflon), in order to maximize the cell performance.

\section{Acknowledgments}

This work was supported by the Ministry of Education and Science of the Spanish Government through project CTM2004-03817, and by the JCCM (Junta de Comunidades de Castilla-La Mancha, Spain) through the project PBI-08-0151-2045.

\section{Nomenclature}

\begin{tabular}{|c|c|c|c|}
\hline $\mathrm{C}_{\mathrm{R}}^{\mathrm{B}}$ & bulk reactant concentration & $\mathrm{S}$ & cross-section \\
\hline $\mathrm{C}_{\mathrm{P}}^{\mathrm{B}}$ & $\begin{array}{l}\text { bulk product reactant } \\
\text { concentration }\end{array}$ & $\Delta \mathrm{P}$ & $\begin{array}{l}\text { pressure different observed } \\
\text { across the carbon support }\end{array}$ \\
\hline $\mathrm{C}_{\mathrm{R}}^{\mathrm{S}}$ & $\begin{array}{l}\text { reactant concentration at the } \\
\text { external surface of the electrode }\end{array}$ & $\mathrm{E}$ & cell voltage \\
\hline $\mathrm{C}_{\mathrm{P}} \mathrm{S}$ & $\begin{array}{l}\text { product concentration at the } \\
\text { external surface of the electrode }\end{array}$ & $\mathrm{E}_{0}$ & open circuit voltage \\
\hline $\mathrm{C}_{\mathrm{R}} \mathrm{C}$ & $\begin{array}{l}\text { reactant concentration at the } \\
\text { catalytic layer }\end{array}$ & $\mathrm{b}$ & Tafel slope \\
\hline $\mathrm{C}_{\mathrm{P}} \mathrm{C}$ & $\begin{array}{l}\text { product concentration at the } \\
\text { catalytic layer }\end{array}$ & $\mathrm{j}$ & experimental current density \\
\hline $\mathrm{C}_{\mathrm{R}^{\text {cat }}}$ & $\begin{array}{l}\text { reactant concentration in the } \\
\text { platinum active sites }\end{array}$ & $\mathrm{R}$ & ohmic resistance of the system \\
\hline$D_{\text {eff }}$ & effective diffusion coefficient & jol & limiting cathode current density \\
\hline $\mathrm{D}$ & diffusion coefficient & jHL & limiting anode current density \\
\hline$\varepsilon$ & porosity & $\mathrm{R}_{\mathrm{pol}}$ & $\begin{array}{l}\text { lineal polarization resistance of } \\
\text { the hydrogen oxidation reaction }\end{array}$ \\
\hline$\tau$ & tortuosity & $\mathrm{R}_{\Omega}$ & $\begin{array}{l}\text { ohmic resistance from } \\
\text { impedance measurement }\end{array}$ \\
\hline K & permeability & $\mathrm{R}_{\mathrm{ct}}$ & $\begin{array}{l}\text { resistance for the charge } \\
\text { transfer process }\end{array}$ \\
\hline Q & flow of gas & $(\mathrm{CPE})_{\mathrm{ct}}$ & $\begin{array}{l}\text { constant phase element for the } \\
\text { charge transfer process }\end{array}$ \\
\hline$\mu$ & gas viscosity & $\mathrm{R}_{\mathrm{mt}}$ & $\begin{array}{l}\text { resistance for the mass transfer } \\
\text { process }\end{array}$ \\
\hline $\mathrm{L}$ & thickness of the porous medium & $(\mathrm{CPE})_{\mathrm{mt}}$ & $\begin{array}{l}\text { constant phase element for the } \\
\text { mass transfer process }\end{array}$ \\
\hline
\end{tabular}

\section{References}

Antolini, E.; Passos, R.R. \& Ticianelli, E.A. (2002). Effects of the cathode gas diffusion layer characteristics on the performance of polymer electrolyte fuel cells. Journal of The Applied Electrochemistry, Vol. 32, No. 4, pp. 383-388, ISSN : 0021-891X. 
Appleby, A.J. \& Foulkes F.R. (1993). Fuel cell handbook, Krieger Publishing Company (Ed.), ISBN: 0-89464-733-4, Malabar, Florida, United State.

Benziger, J.; Nehlsen, J.; Blackwell, D.; Brennan, T. \& Itescu, J. (2005). Water flow in the gas diffusion layer of PEM fuel cells. Journal of Membrane Science, Vol. 261, No. 1-2, (September 2005), pp. 98-106, ISSN: 0376-7388.

Bose, S.; Kuila, T.; Hien Nguyen, T.X.; Kim, N.H; Lau, K.-T. et al. (2011). Polymer membranes for high temperature proton exchange membrane fuel cell: Recent advances and challenges. Journal of Power Sources, in press, (January 2011), doi:10.1016/j.progpolymsci.2011.01.003, ISSN: 0378-7753.

Boukamp. B.A. (1986). A package for impedance/admittance data analysis. Solid State Ionics, Vol. 18-19, Part 1, (January 1986), pp. 136-140, ISSN: 0167-2738

Bultel, Y.; Wiezell, K.; Jaouen, F.; Ozil, P. \& Lindbergh G. (2005). Investigation of mass transport in gas diffusion layer at the air cathode of a PEMFC. Electrochimica Acta, Vol. 51, No. 3, (October 2005), pp. 474-488, ISSN: 0013-4686.

Carrete, L.; Friedrich, K.A. \& Stimming, U. (2001). Fuel Cells - Fundamentals and Applications. Fuel Cells, Vol. 1, No. 1, (May 2001), pp. 5-39, ISSN: 1615-6854.

Cindrella, L. ; Kannan, A.M.; Lin, J.F.; Saminathan K.; Ho Y. et al. (2009). Gas diffusion layer for proton exchange membrane fuel cells-A review. Journal of Power Sources, Vol. 194, No. 1, (October 2009), pp. 146-160. ISSN: 0378-7753.

Ciureanu, M. \& Roberge R. (2001). Electrochemical Impedance Study of PEM Fuel Cells. Experimental Diagnostics and Modeling of Air Cathodes. Journal of Physical Chemistry B, Vol. 105, No. 17, (April 2001), pp 3531-3539, ISSN: 1089-5647.

Ciureanu, M.; Mikhailenko, S.D.; Kaliaguine, S. (2003). PEM fuel cells as membrane reactors: kinetic analysis by impedance spectroscopy. Catalysis Today, Vol. 82, No. 1-4, (July 2003), pp. 105-206, ISSN 0920-5861.

EG\&G Technical Services, Inc. (2004). Fuel Cell Handbook (7th Edition), U.S. Department of Energy Office of Fossil Energy, Morgantown, West Virginia, United State. Available from

http://www.netl.doe.gov/technologies/coalpower/fuelcells/seca/pubs/FCHandb ook7.pdf.

Han, M.; Xu, J.H.; Chan, S.H. \& Jiang, S.P. (2008). Characterization of gas diffusion layers for PEMFC.

Electrochimica Acta, Vol. 53, No. 16, (June 2008), pp. 5361-5367, ISSN: 0013-4686.

Jalani, N.H.; Ramani, M.; Ohlsson, K.; Buelte, S.; Pacifico, G. et al. (2006). Performance analysis and impedance spectral signatures of high temperature PBI-phosphoric acid gel membrane fuel cells. Journal of Power Sources, Vol. 160, No. 2, (October 2006), pp. 10961103, ISSN: 0378-7753.

Lai, C.-M.; Lin, J.-C.; Ting F.-P.; Chyou, S.-D. \& Hsueh K.-L. (2008). Contribution of Nafion loading to the activity of catalysts and the performance of PEMFC. International Journal of Hydrogen Energy, Vol. 33, No. 15, (August 2008) pp. 4132-4137, ISSN: 03603199.

Li, Q.; He, R.; Jensen, J.O. \& Bjerrum, N.J. (2003a). Review Approaches and Recent Development of Polymer Electrolyte Membranes for Fuel Cells Operating above 100 ${ }^{\circ} \mathrm{C}$. Chemistry of Materials, Vol. 15, No. 26, (December 2003), pp 4896-4915, ISSN: 08974756.

Li, Q.; He, R.; Gao, J.-A.; Jensen, J.O. \& Bjerrum, N.J. (2003b). The CO Poisoning Effect in PEMFCs Operational at Temperatures up to $200^{\circ} \mathrm{C}$. Journal of The Electrochemical Society, Vol. 150, No. 12, (November 2003), pp.A1599-A1605, ISSN: 0013-4651. 
Li, Q.; He, R.; Jensen, J.O. \& Bjerrum, N.J. (2004). PBI-Based Polymer Membranes for High Temperature Fuel Cells - Preparation, Characterization and Fuel Cell Demonstration. Fuel Cells, Vol. 4, No. 3, (August 2004), pp. 147-159, ISSN: 1615-6854.

Linares, J.J. (2010). Celdas de combustible de membrana polimérica de alta temperatura basadas en polibencimidazol impregnado con ácido fosfórico. PhD Thesis Dissertation, (January 2010), Ciudad Real, Spain.

Liu, Z.; Wainright, J.S.; Litt, M.H. \& Savinell R.F. (2006). Study of the oxygen reduction reaction (ORR) at Pt interfaced with phosphoric acid doped polybenzimidazole at elevated temperature and low relative humidity. Electrochimica Acta, Vol. 51, No. 19, (May 2006), pp. 3914-3923, ISSN: 0013-4686.

Lobato, J.; Cañizares, P.; Rodrigo, M.A.; Linares, J.J. \& Manjavacas G. (2006). Synthesis and characterisation of poly[2,2-(m-phenylene)-5,5-bibenzimidazole] as polymer electrolyte membrane for high temperature PEMFCs. Journal of Membrane Science, Vol. 280, No. 1-2, (September 2006), pp. 351-362, ISSN: 0376-7388.

Lobato, J.; Cañizares, P.; Rodrigo, M.A.; Linares, J.J. \& López-Vizcáino, R. (2008a). Performance of a Vapor-Fed Polybenzimidazole (PBI)-Based Direct Methanol Fuel Cell. EnergyEFuels, Vol. 22, No. 5, (July 2008), pp 3335-3345, ISSN: 0887-0624.

Lobato, J.; Cañizares, P.; Rodrigo M.A.; Ruíz-López, C. \& Linares, J.J. (2008b). Influence of the Teflon loading in the gas diffusion layer of PBI-based PEM fuel cells. Journal of The Applied Electrochemistry, Vol. 38, No. 6, pp. 793-802, ISSN: 0021-891X

Lobato, J.; Cañizares, P.; Rodrigo, M.A.; Linares, J.J. \& Pinar, F.J. (2010a). Study of the influence of the amount of PBI-H3PO4 in the catalytic layer of a high temperature PEMFC. International Journal of Hydrogen Energy, Vol. 35, No. 3, (February 2010), pp. 1347-1355, ISSN: 0360-3199.

Lobato, J.; Cañizares, P.; Rodrigo, M.A; Úbeda, D.; Pinar F.J. et al. (2010b). Optimisation of the Microporous Layer for a Polybenzimidazole-Based High Temperature PEMFC Effect of Carbon Content. Fuel Cells, Vol. Vol. 10, No. 5, (October 2010), pp. 770-777, ISSN: $1615-6854$.

Mamlouk, M. \& Scott, K. (2010). The effect of electrode parameters on performance of a phosphoric acid-doped PBI membrane fuel cell. International Journal of Hydrogen Energy, Vol. 35, No. 2, (January 2010), pp. 784-793, ISSN: 0360-3199.

Mathias, M.; Roth, J.; Fleming, J. \& Lehnert W. (2003). Diffusion media materials and characterisation, in: Handbook of Fuel Cells, W. Vielstich, A. Lamm, H. A. Gasteiger (Eds.), John Wiley \& Sons Ltd, Ch. 46, Chichester, United Kingdom, ISBN: 0-47149926-9

Paganin, V.A.; Oliveira, C.L.F.; Ticianelli, E.A.; Springer, T.E. \& González, E.R. (1998). Modelistic interpretation of the impedance response of a polymer electrolyte fuel cell. Electrochimica Acta, Vol. 43, No. 24, (August 1998), pp. 3761-3766, ISSN: 0013-4686.

Pan, C.; Li, Q.; Jensen, J.O.; He, R.; Cleeman, L.N. et al. (2007). Preparation and operation of gas diffusion electrodes for high-temperature proton exchange membrane fuel cells. Journal of Power Sources, Vol. 172, No. 1, (October 2007), pp. 278-286, ISSN: 0378-7753.

Park, S.; Lee, J.-W. \& Popov, B.N. (2006). Effect of carbon loading in microporous layer on PEM fuel cell performance. Journal of Power Sources, Vol. 163, No. 1, (December 2006), pp. 357-363, ISSN: 0378-7753.

Park, G.-G.; Sohn, Y.-J.; Yang T.-H.; Yoon, Y.-G.; Lee, W.-Y. et al. (2004). Effect of PTFE contents in the gas diffusion media on the performance of PEMFC. Journal of Power Sources, Vol. 131, No. 1-2, (May 2004), pp. 182-187, ISSN: 0378-7753. 
Prasanna, M.; Ha, H.Y. \& Cho, E.A. (2004a). Influence of cathode gas diffusion media on the performance of the PEMFCs. Journal of Power Sources, Vol. 131, No. 1-2, (May 2004), pp. 147-154, ISSN: 0378-7753.

Prasanna, M.; Ha, H.Y.; Cho, E.A.; Hong, S.-A.; Oh, I.-H. (2004b). Investigation of oxygen gain in polymer electrolyte membrane fuel cells. Journal of Power Sources, Vol. 137, No. 1, (October 2004), pp. 1-8, ISSN: 0378-7753.

Quingfeng, L.; Hjuler, H.A. \& Bjerrum, N.J. (2000). Oxygen reduction on carbon supported platinum catalysts in high temperature polymer electrolytes. Electrochimica Acta, Vol. 45, No. 25-26, (August 2000), pp. 4219-4226, ISSN: 0013-4686.

Samms, S.R.; Wasmus, S.; Savinell, R.F. (1996). Thermal Stability of Proton Conducting Acid Doped Polybenzimidazole in Simulated Fuel Cell Environments. Journal of The Electrochemical Society, Vol. 143, No. 4, (April 1996), pp. 1225-1232, ISSN: 0013-4651.

Savadogo, O. (2004). Emerging membranes for electrochemical systems: Part II. High temperature composite membranes for polymer electrolyte fuel cell (PEFC). Journal of Power Sources, Vol. 127, No. 1-2, (March 2004), pp. 135-161, ISSN: 0378-7753.

Seland, F.; Berning, T.; Børresen, B. \& Tunold R. (2006). Improving the performance of hightemperature PEM fuel cells based on PBI electrolyte. Journal of Power Sources, Vol. 160, No. 1, (September 2006), pp. 27-36, ISSN: 0378-7753.

Soler, J.; Hontañón, E. \& Daza, L. (2003). Electrode permeability and flow-field configuration: influence on the performance of a PEMFC. Journal of Power Sources, Vol. 118, No. 1-2, (May 2003), pp. 172-178, ISSN: 0378-7753.

Song, J.M.; Cha, S.Y. \& Lee, W.M. (2001). Optimal composition of polymer electrolyte fuel cell electrodes determined by AC impedance method. Journal of Power Sources, Vol. 94, No. 1, (February 2001), pp. 78-84, ISSN: 0378-7753.

Springer, T.E.; Zawodzinski, T.A.; Wilson, M.S.; Gottesfeld, S. (1996). Characterization of Polymer Electrolyte Fuel Cells Using AC Impedance Spectroscopy. Journal of The Electrochemical Society, Vol. 143, No. 2, (February 1996), pp. 587-599, ISSN: 0013-4651.

Wainright, J.S.; Litt, M.H. \& Savinell R.F. (2003). High Temperatures membranes, in: Handbook of Fuel Cells, W. Vielstich, A. Lamm, H. A. Gasteiger (Eds.), John Wiley \& Sons Ltd, Vol. 3, Chichester, United Kingdom, ISBN: 0-471-49926-9.

Wang, J.-T.; Wasmus, S. \& Savinell, R.F. (1996). Real-Time Mass Spectrometric Study of the Methanol Crossover in a Direct Methanol Fuel Cell. Journal of The Electrochemical Society, Vol. 143, No 4, (April 1996), pp. 1233-1239, ISSN: 0013-4651.

Wang, X.L.; Zhang, H.M.; Zhang, J.L.; Xu, H.F.; Tian Z.Q. et al. (2006). Micro-porous layer with composite carbon black for PEM fuel cells. Journal of Power Sources, Vol. 51, No. 23, (June 2006), pp. 4909-4915, ISSN: 0378-7753.

Weng, D.; Wainright, J.S.; Landau, U. \& Savinell, R.F. (1996). Electro-osmotic Drag Coefficient of Water and Methanol in Polymer Electrolytes at Elevated Temperatures. Journal of The Electrochemical Society, Vol. 143, No. 4, (April 1996), pp. 1260-1263, ISSN: 00134651.

Williams, M.V.; Begg, E.; Bonville, L.; Kunz H.R. \& Fenton, J.M. (2004). Characterization of Gas Diffusion Layers for PEMFC. Journal of The Electrochemical Society, Vol. 151, No. 8, (June 2004), pp. A1173-A1180, ISSN: 0013-4651.

Yuan, X.; Wang, H.; Sun, J.C. \& Zhang, J. (2007). AC impedance technique in PEM fuel cell diagnosis-A review. International Journal of Hydrogen Energy, Vol. 32, No. 17, (December 2007), pp. 4365-4380, ISSN: 0360-3199. 


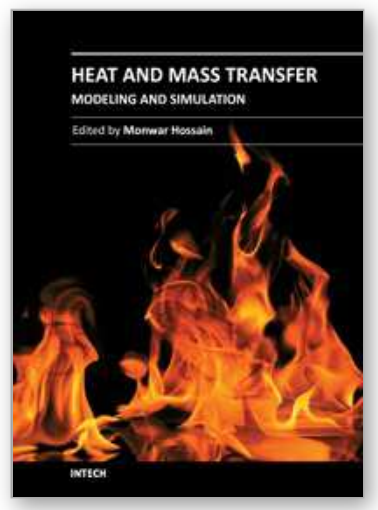

\author{
Heat and Mass Transfer - Modeling and Simulation \\ Edited by Prof. Md Monwar Hossain
}

ISBN 978-953-307-604-1

Hard cover, 216 pages

Publisher InTech

Published online 22, September, 2011

Published in print edition September, 2011

This book covers a number of topics in heat and mass transfer processes for a variety of industrial applications. The research papers provide advances in knowledge and design guidelines in terms of theory, mathematical modeling and experimental findings in multiple research areas relevant to many industrial processes and related equipment design. The design of equipment includes air heaters, cooling towers, chemical system vaporization, high temperature polymerization and hydrogen production by steam reforming. Nine chapters of the book will serve as an important reference for scientists and academics working in the research areas mentioned above, especially in the aspects of heat and mass transfer, analytical/numerical solutions and optimization of the processes.

\title{
How to reference
}

In order to correctly reference this scholarly work, feel free to copy and paste the following:

Justo Lobato, Pablo Cañizares, Manuel A. Rodrigo and José J. Linares (2011). The Gas Diffusion Layer in High Temperature Polymer Electrolyte Membrane Fuel Cells, Heat and Mass Transfer - Modeling and Simulation, Prof. Md Monwar Hossain (Ed.), ISBN: 978-953-307-604-1, InTech, Available from: http://www.intechopen.com/books/heat-and-mass-transfer-modeling-and-simulation/the-gas-diffusion-layer-inhigh-temperature-polymer-electrolyte-membrane-fuel-cells

\section{INTECH}

open science | open minds

\author{
InTech Europe \\ University Campus STeP Ri \\ Slavka Krautzeka 83/A \\ 51000 Rijeka, Croatia \\ Phone: +385 (51) 770447 \\ Fax: +385 (51) 686166 \\ www.intechopen.com
}

\author{
InTech China \\ Unit 405, Office Block, Hotel Equatorial Shanghai \\ No.65, Yan An Road (West), Shanghai, 200040, China \\ 中国上海市延安西路65号上海国际贵都大饭店办公楼 405 单元 \\ Phone: +86-21-62489820 \\ Fax: +86-21-62489821
}


(C) 2011 The Author(s). Licensee IntechOpen. This chapter is distributed under the terms of the Creative Commons Attribution-NonCommercialShareAlike-3.0 License, which permits use, distribution and reproduction for non-commercial purposes, provided the original is properly cited and derivative works building on this content are distributed under the same license. 